\title{
The Development of Multicultural Communication Patterns Based on Local Wisdom in Ampenan City, West Nusa Tenggara
}

\author{
Suciati $1^{1, *}$ Nur Sofyan ${ }^{1}$ \\ ${ }^{1}$ Communication Department, Universitas Muhammadiyah Yogyakarta, Indonesia \\ *Corresponding author. Email: Suciati@umy.ac.id
}

\begin{abstract}
This study aims to describe the development of multicultural communication patterns based on local wisdom in Ampenan City, West Nusa Tenggara (NTB). The efforts of the local government to integrate into harmony in Ampenan City, NTB, received a positive response from various parties as it could inspire other multicultural cities in harmonizing communication between people of different cultures. To achieve the goal, the study used a qualitative approach with a case study design. The benefit of the research is that it wants to make a practical contribution, namely discovering a model for developing multicultural communication patterns based on local wisdom in Ampenan, NTB. With the cultural background of Ampenan City people (Sasak, Malay, Chinese, Bugis), this research has produced a national integration model toward harmony. The data collection used in-depth interviews and Focus Group Discussion (FGD). Data analysis was performed using interactive analysis. To test the data validity, this study utilized the triangulation of sources, methods, and researchers. Several things supporting assimilation in Ampenan include past experiences, equal opportunities in the economic field, tolerance in religion, absence of dominant ethnicity in social interactions, use of regional languages in interethnic interactions, mixed marriages (amalgamation), and roles of Local Government in fostering the existing harmony. These factors support assimilation to produce a form of social interaction without being colored by conflict.
\end{abstract}

Keywords: amalgamation, harmonization, tolerance, local wisdom, multicultural communication patterns

\section{INTRODUCTION}

As social beings, humans interact with those having something in common. In the current global era, the means of transportation, communication, and information are to bridge geographic differences and ease humans to interact with one another. In social life, symbols become tools for individuals to interact with others. In this interaction, there is also an exchange of nonverbal symbols. The abilities of humans to build cultural traditions, create an understanding of reality expressed symbolically, and pass it on to future generations, are highly dependent on language. The cultural meaning underlying people's life is formed from the relationship between symbols or language.

Several regions in Indonesia show a high multiculturalism attitude, one of which is on Lombok Island, located in West Nusa Tenggara Province. Most of the current Sasak people in Lombok are village people, predominantly Muslims, built on a foundation of spirituality, animism, Hinduism, and Buddhism, causing the Sasak people to become a multiethnic culture, multiculturalism, and acculturation. In terms of association, each ethnic group can live independently without disturbing each other, thus with culture and religion. Especially in Ampenan, this port city is inhabited by at least the Sasak people as natives, Malays, and Chinese (Saputro, 2018). Meanwhile, Topat Wars are usually carried out before the rice planting season and after the rainy season. The buffalo is a symbol of respect for Muslims and Hindus. What a beautiful reality wrapped in total awareness that we are all creatures of Allah SWT, to knit brotherhood and peace. Hence, the Topat War philosophy maintains the tradition of maintaining tolerance (CNN Indonesia, December 2019).

Zaremba (2012) researched tolerance as a value of local wisdom possessed by the Sasak people entitled Sasak Local Wisdom Values with Multicultural Insights to Build Community Social Integration in West Lombok. The results showed that the values of Sasak local wisdom played a role as a guide for community life in politics, social society, trade economics, agriculture, and the preservation of cultural customs, as a communication bridge, creating harmony, mutual respect between ethnic groups, and fostering inter-ethnic tolerance. 
In a multicultural context, local wisdom is very close to developing a tolerant attitude between different cultures. As found in research by Mustain et al. (2013), to build peaceful communication and develop a tolerant attitude, interfaith communities in the Lombok Island region developed local wisdom that has developed from generation to generation. Mustain took an example with the expression "jauh batik mesak", which means taking and holding your own opinion and not blaming others. This expression can be interpreted as an effort every person must stick to the teachings of their religion, but still have to respect other religious teachings. Everyone is not allowed to insult and abuse the teachings of other religions.

Some research on multiculturalism, among others as carried out by Merkin (2009). He investigated the multicultural communication patterns between Korea and America entitled Cross-cultural communication patterns - Korean and American Communication. It revealed that Koreans used less direct and more indirect communication than US Americans and that Koreans were also more communicatively apprehensive and less nonverbally immediate than their US American counterparts. Tests on culture and verbal aggressiveness were insignificant. An adaptation is also required in the effectiveness of intercultural communication. A study entitled Measuring communication patterns and intercultural transformation of international students in crosscultural adaptation was carried out by ZhongPeng and Wei-PingWu (2019), discovering four main pathways (host communication competence, host social communication, intercultural transformation basic, intercultural transformation advanced) essential for the development of international students cross-cultural adaptation, and the interlocking bilateral relationships among these pathways were significant and positive. This study provides an insightful theoretical foundation for investigating international students' cross-cultural adaptation in non-western contexts and the compelling empirical support on the structural model of crosscultural adaptation. The obstacles of a multicultural study were examined by Rodgers and McGovern (2002) entitled Attitudes toward the culturally different: the role of intercultural communication barriers, affective responses, consensual stereotypes, and perceived threat. Intercultural communication emotions (negative effect associated with perceived linguistic and cultural barriers) were investigated as determinants of prejudice, in conjunction with causal factors widely recognized as central to intergroup judgments (consensual stereotypes, intergroup anxiety, and realistic and symbolic/cultural threats). Based on this description, the main question is how to develop multicultural communication patterns based on local wisdom in Ampenan City, West Nusa Tenggara toward harmonization, and what factors are influencing?

\section{DISCUSSION}

\subsection{The meaning of local wisdom}

In the context of intercultural communication in Ampenan, several messages supporting effectiveness are messages in their local wisdom. The meaning of multicultural communication in the Ampenan community can be categorized as follows:

Table 1. Meanings of Local Wisdom in Ampenan, Mataram, NTB

\begin{tabular}{|c|c|c|}
\hline No. & $\begin{array}{c}\text { Local } \\
\text { wisdom } \\
\text { name }\end{array}$ & $\begin{array}{c}\text { Meaning in the context of } \\
\text { multicultural } \\
\text { communication }\end{array}$ \\
\hline 1. & Pepaosan & $\begin{array}{l}\text { Increasing love for the } \\
\text { Prophet Muhammad and } \\
\text { imitating him }\end{array}$ \\
\hline 2. & Peresean & $\begin{array}{l}\text { A balance between men and } \\
\text { women }\end{array}$ \\
\hline 3. & $\begin{array}{l}\text { Rowah } \\
\text { Kokoq }\end{array}$ & $\begin{array}{l}\text { Love for the natural } \\
\text { environment }\end{array}$ \\
\hline 4. & $\begin{array}{l}\text { Nguwur siq } \\
\text { Kesangkur }\end{array}$ & $\begin{array}{l}\text { A balance in social, national, } \\
\text { state and religious life }\end{array}$ \\
\hline 5. & $\begin{array}{l}\text { Tindih, } \\
\text { maliq, } \\
\text { merang }\end{array}$ & $\begin{array}{l}\text { Manifesting human beings } \\
\text { always to be calm and serene }\end{array}$ \\
\hline 6. & $\begin{array}{l}\text { Tatas, Tuhu, } \\
\text { Trasna }\end{array}$ & $\begin{array}{l}\text { Correcting social interaction } \\
\text { while developing obligations } \\
\text { according to religion }\end{array}$ \\
\hline 7. & $\begin{array}{l}\text { Patuh, } \\
\text { patut, patcu }\end{array}$ & \multirow{2}{*}{$\begin{array}{l}\text { Maintaining a harmonious } \\
\text { relationship with the Creator } \\
\text { of the universe as proof of } \\
\text { obedience }\end{array}$} \\
\hline 8. & $\begin{array}{l}\text { Solah, } \\
\text { Saleh, Soloh }\end{array}$ & \\
\hline 9. & $\begin{array}{l}\text { Traditional } \\
\text { ritual }\end{array}$ & $\begin{array}{l}\text { Maintaining a balanced } \\
\text { relationship with God, } \\
\text { humans, and the universe }\end{array}$ \\
\hline 10. & $\begin{array}{l}\text { Customary } \\
\text { law }\end{array}$ & $\begin{array}{l}\text { Sanctions for people who } \\
\text { violate religious laws, } \\
\text { community agreements, and } \\
\text { destruction of the universe }\end{array}$ \\
\hline 11. & $\begin{array}{l}\text { Mbe Lain } \\
\text { Aiq Ngeleq }\end{array}$ & $\begin{array}{l}\text { Education in the family is an } \\
\text { essential requirement for the } \\
\text { creation of a child's } \\
\text { personality }\end{array}$ \\
\hline 12. & $\begin{array}{l}\text { Home } \\
\text { architectural } \\
\text { philosophy }\end{array}$ & $\begin{array}{l}\text {-a symbol of politeness and } \\
\text { respect for guests } \\
\text {-symbol of frugality } \\
\text {-symbol of the process of } \\
\text { human life: birth, growth, } \\
\text { death. }\end{array}$ \\
\hline
\end{tabular}




\begin{tabular}{|c|l|l|}
\hline No. & \multicolumn{1}{|c|}{$\begin{array}{c}\text { Local } \\
\text { wisdom } \\
\text { name }\end{array}$} & $\begin{array}{c}\text { Meaning in the context of } \\
\text { multicultural } \\
\text { communication }\end{array}$ \\
\hline 13. & Besiru & Solidarity with others \\
\hline 14. & Nyongkolan & $\begin{array}{l}\text { Gathering for the sake of } \\
\text { family harmony in the house }\end{array}$ \\
\hline 15. & Ngejot & $\begin{array}{l}\text { Gratitude for fortune and the } \\
\text { spirit to share with others }\end{array}$ \\
\hline
\end{tabular}

Source: researcher documentation data, 2019

Table 1 implies that the local wisdom possessed by the Sasak people in general and Ampenan, in particular, is based on three strengths, namely maintaining harmony between the Creator, fellow humans, and the universe. The categorization of local wisdom is presented in harmony with God, humans, and the universe.

\subsection{Tolerance as the value of local wisdom}

Religion, as a most sensitive form of culture, has been able to tolerate the Ampenan community. In this society, religions are diverse, including Islam (embraced by the Sasak, Bugis, and Arab communities), Confucian (embraced by the Chinese community), and Hindus embraced by some Ampenan communities. Multicultural communication models still prioritize melting and tolerance. Melting is in the sense of not being exclusive to each other. Being more tolerant means respecting other religions. The form of melting is the use of a specific ethnic language for interethnic mixing. The language used for everyday life is Indonesian or Sasak.

People who belong to an extrinsic religion use religion as a tool to achieve non-religious goals. Extrinsic religious orientation motifs are limited to social or visible values and beliefs. This type is the image of a person pursuing goals for personal gain and using religion to achieve social status and power. Extrinsic religion is said to be a sign that a person is less mature in religion than intrinsic. Therefore, it is clear that interfaith conflict is thought to be influenced by an extrinsic religious orientation, or using religion as a tool to achieve a goal, not the goal of religion, but personal interests, or using religion to achieve social position and power (Azra in Harahap, 2018 ).

Based on Harahap's statement, the people of Ampenan have an intrinsic religious orientation. When they practice tolerance not to pursue the interests of their respective ethnic groups, the application of religious values combined with local wisdom can build effective multicultural communication among fellow immigrants in general and natives. The religious values that they apply in the communication process remain sourced in the harmony of relationship with God, with each other, and with the universe.

Conceptually, the implications of religious tolerance in Ampenan in multicultural society can be seen through the following three forms:

1. A mixed social interaction between ethnicity and religion in Ampenan

2. Cooperation, such as arisan gawai (regular social gathering to own gadget) or arisan kematian (a gathering to help a family losing their family member due to death), belalik, and gotong-royong (mutual assistance), which has a function as a social adhesive, a social capital and can strengthen the identity of the group through a special moment

3. Religious freedom practice and Christmas celebrations on a shared kosher dietary bill (Hemafitria, 2019)

\subsection{Cultural assimilation of the Ampenan community}

Acculturation, according to Kim, is the process of learning and internalizing the culture and values embraced by indigenous peoples. Furthermore, Kim defines acculturation as a process undertaken by immigrants to adapt to and acquire indigenous cultures, leading to assimilation (Mulyana and Rahmat, 2005). The meaning and position of acculturation in the context of inter-ethnic realization becomes clearer when presenting the meaning of assimilation. Park and Burgess call assimilation a process of interpretation and fusion. Through this process, people and groups acquire the memories, sentiments, and attitudes of other people or groups, with various experiences and histories, to join them in common cultural life. The assimilation process in Ampenan involves historical experience, language sentiments, and religious sentiments. Historical experience proves that ethnic Arabs and Chinese are immigrant nations engaged in trade through ports. Although only a subdistrict in Mataram NTB, Ampenan was formerly known by its nickname as a port city and a trading center. Although it is quite the past and only historical records remain, several generations continue the business. During the colonial period, 1948-1950, Ampenan was the largest trade and business center in NTB.

Their language and religious sentiments and the attitude of tolerance they developed became sufficient capital in establishing assimilation in Ampenan. Religious and linguistic sentiments are not directed at negative sentiments. However, the feelings that arise due to the differences between the two are sought for a peaceful path, not a conflict. They choose to use the local language in inter-ethnic communication, while in religious ceremonies, they participate in it even though they do not have to follow rituals. In economic sentiment, their position is the same as traders and immigrants. Although each region's ethnic sentiment is complex, such as the emergence of Malay, Bugis, Arab, and Chinese villages, it does not mean that it is the reason for the development of ethnocentrism (Antaranews.com, July 2019). 
The meaning of assimilation reflects a relationship between two groups, where one group is an indigenous community usually dominant, with one minority group, usually a community or individual immigrant or migrant. In this condition, the minority groups will gradually lose their identity during the assimilation. According to Jiobu (1988), assimilation can give rise to two possible consequences, namely:

1) The minority group loses its uniqueness and resembles the majority group. In the process, the majority group does not change.

2) Minority groups and majority groups mix homogeneously

Based on these assimilation results, there is a second possibility in Ampenan. It means that each ethnic group assimilates culture. They celebrate the religious holidays of other religions and participate in enlivening the cultural traditions of the Sasak ethnic group, with nuances of local wisdom.

In classifying the dimensions of assimilation, Gordon distinguishes it into seven dimensions, namely: cultural or behavioral assimilation (acculturation), structural, marital, identification, acceptance of the attitude, acceptance of behavior, and nationality. Based on these dimensions of assimilation, the assimilation of the Ampenan people belongs to the cultural assimilation. Their assimilation is in terms of habits. Meanwhile, according to Mulyana, acculturation is a sub-process of assimilation. It suggests a gradual replacement of the cultural characteristics of minority groups by those of indigenous people. However, acculturation also shows that members of minority groups may retain some of their original characteristics and discard other characteristics, while at the same time, they may also accept some of the dominant cultural characteristics and reject other characteristics (Mulyana and Rahmat, 2005). Assimilation and acculturation are two concepts frequently appearing in the discourse of inter-ethnic relations. The two concepts are always related to one another. Kim said that assimilation is the highest degree of acculturation. In the middle of the relationship between assimilation and acculturation, to a certain extent, the two have different aspects. Mulyana, for example, considers that acculturation is a two-way process, while assimilation is a one-way process. Other scientists sometimes do not distinguish between the two concepts. Gillin and Gillin parallel the two concepts when describing their possible emergence. According to Gillin and Gillin, assimilation and acculturation can occur due to:

(1) loyalty and social harmony

(2) opportunities in the economic field

(3) cultural equality

(4) mixed marriage

(5) a threat from the outside
In the case of the Ampenan people, according to Gilin and Gilin, they correspond to points 1, 2, and 4 . Social loyalty and harmony can be seen when there are rarely conflicts between indigenous ethnic groups and ethnic immigrants. The implementation of tolerance and assimilation in Ampenan can run effectively due to the multiculturalism awareness, the responsibility of all parties. This awareness is in the form of a willingness to accept and appreciate differences. It can occur with continuous socialization to the various ethnic communities living in Ampenan. Also, the formation of interfaith communities in this area aims to support effective communication. The awareness of multiculturalism in this area can be directed to build a national identity, national integration, and awareness of placing religion for national unity. It will make Indonesian unity enforceable in line with Bhinneka Tunggal Ika (Juditha, 2015).

The supporting factors for multiculturalism in this area include: first, indigenous tribes do not have social jealousy. As an indigenous tribe, this Sasak tribe has an enormous tolerance for immigrant tribes. They have never felt social jealousy that more migrants have a higher economy. In terms of economic growth related to city trade, ethnic groups outside the Sasak tribe have experienced better economic growth than the indigenous population. Second, there is no regional sentiment among ethnic groups in the Ampenan community. Even though the settlements carry their respective ethnic names, each ethnic group does not feel competitive. The cultural assimilation of each ethnicity can be seen from inter-ethnic marriage or amalgamation. However, the marriage still prioritizes religious equality. Third, the use of Indonesian in interethnic communication. The role of the Indonesian language as a unifying part is applied. Each ethnic group carries its language. However, each ethnic group still limits the use of ethnic language when associating with other ethnicities, even though each maintains the existence of their mother tongue. Apart from that, there is also the language of the acculturation results: ana merjak dulu. Many people do not understand, meaning "I want to go home first". The language of children today, the slang of children in the Malay village, is not Sasak, not Indonesian, not Arabic but a combination of various languages.

Fourth, the role of government in harmonization in a multicultural climate. In Mataram, the indigenous Sasak tribe occupies the largest number, and Islam becomes the most widely practiced religion. Relations between members of the Ampenan community are going well, as is the relationship between the community and the Mataram City Government. The parties carry out various activities by guiding pecalang, security in customary activities, and various other collaborations involving both parties. The "pecalang" security is present in every traditional village, which has traditionally been passed down from generation to generation in Balinese culture. Pecalang is tasked with 
securing and ordering traditional villages, both in daily life and in conjunction with organizing traditional or religious ceremonies. It also happens with certain groups that represent existing community groups.

The local government always invites and actively involves the community in various government implementation activities and resolves the problems faced by Mataram. The issues discussed began with resolving conflicts in the community. This effort is in line with efforts to implement one of the basic strategies to keep regional autonomy running. The role of public control as a concrete form of public participation is raised. Autonomy is part of democratization based on empowering local communities. It demands strict prerequisites from the government and society, especially regarding changes in people's mindset so that they are no longer just spectators but must be ready to become a major role in the national development process (Basuni 2001).

The local government in Mataram has tried to accommodate local wisdom into various programs in the community. These programs aim to create harmony and equalize the vision and mission of the local government with other components of society. The administration of government in the regions is also a democratic government. People's political aspirations and participation in the regions are indeed articulated effectively and become a paradigm in the proportional decision-making process and public policy. Thus, there will be enlightenment for people's democracy, starting from the people who believe, are happy and satisfied, and support the administration of their government. Undoubtedly, it can happen based on the credibility and performance of a clean government. People have a sense of belonging that the government belongs to them, involved in it and that the government protects them (Nihin, 1999).

There are several independent security organizations in Mataram, including Pecalang, LangLang, Banyu Mandala, the Taman Mandala Youth Association, Nyiurlembang, and others. They have an essential role in harmonizing the Ampenan community. Pam Swakarsa organization is part of the local wisdom of religion, while Taman Mandala is a formation of the Sasak indigenous community. Such organizations greatly assist national defense and security efforts even though they are on a local scale, especially in Ampenan, Lombok, NTB (Indrawan, 2014).

In short, the multicultural communication model in the Ampenan community, Lombok, NTB, is as follows:

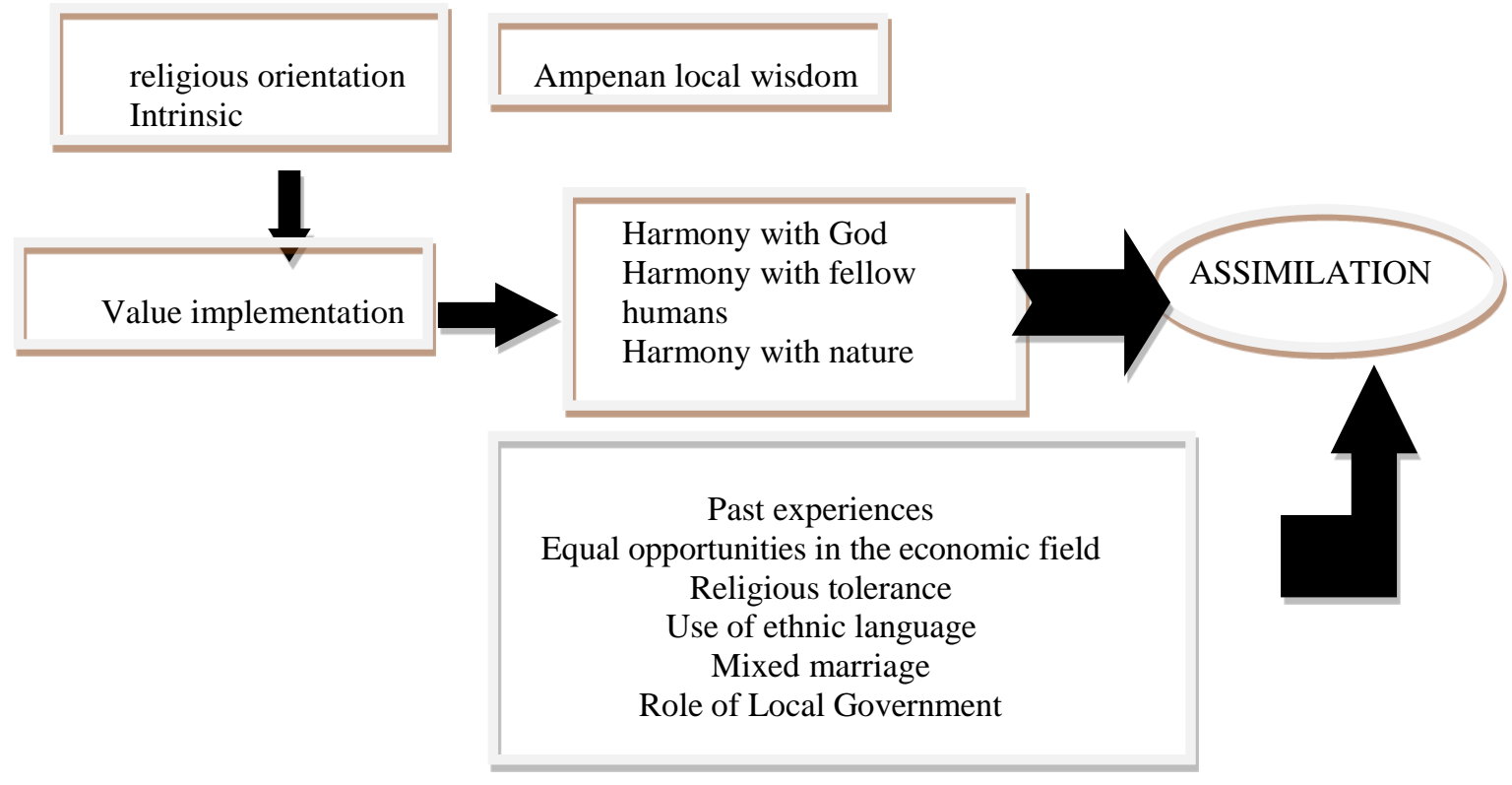

\section{CONCLUSIONS}

There are four requirements that individuals need to communicate effectively between cultures, including respecting members of other cultures as human beings, respecting other cultures as they are, not as we want, respecting the rights of other cultural members to act differently from the way we act, and cross-cultural communicators competent people must learn to enjoy living with people from other cultures. These four conditions have been fulfilled by the
Ampenan people, with various ethnicities in them. They do not differentiate between indigenous and immigrant. They do not require other ethnicities to follow their cultural traditions. Tolerance is developed through friendship and prioritizes togetherness in local wisdom rituals and avoiding conflicts with one another. The role of local wisdom in Ampenan is to unify by strengthening the character in a multicultural society. The multicultural communication pattern in the Ampenan community, Mataram NTB, is based on cultural assimilation/acculturation based on local wisdom. Local wisdom has dimensions of harmonious 
relations between man and God, man and man, and man and the universe.

Several factors support assimilation in Ampenan, including experience, equal opportunity in the economic field, tolerance in religion, absence of dominant ethnicity in social interactions among them, use of regional languages in inter-ethnic interactions, and mixed marriages (amalgamation). Moreover, the role of the Regional Government is fostering the existing harmony. These factors support assimilation to produce a form of social interaction without being colored by conflict. Local wisdom values also support the religious orientation based on intrinsic religious orientation in three relationship dimensions. The success of assimilation in Ampenan occurs because local wisdom values follow the values in the religion and culture of the local community. Each ethnic group can understand other cultures and believe that their culture is not the best.

\section{REFERENCES}

Mulyana, D dan Rakhmat, J. (2005). Komunikasi Antarbudaya, Bandung: PT Remaja Rosdakarya

Nihin, H.A, Dj. (1999). Paradigma Baru pemerintahan Daerah Menyongsong Milenium Ketiga, Jakarta: Mardi Mulya

Jiobu, Robert M. (1988). Ethnicity and Assimilation, New York: State Univ of New York Pr, 1988

Journals:

Mustain, dkk (2013). Segregasi Etno-Religius: Upaya Resolusi Konflik dan Pembangunan Perdamaian. Mataram: Jurnal Walisongo Vol. 21 Nomor 1, Mei 2013.

Basuni, Sambas. (2001) Tinjauan terhadap Pembangunan Sistem Kawasan dan Otonomi (Ecotourism, Conservation Management and Regional Government Autonomy) Jurnal Media Konservasi, Volume VII/No 2, Juni, 2001

Hemafitria (2019). Konflik Antar Etnis Melalui penguatan Multikultural. Jurnal Pendidikan Kewarganegaaraan Volume 3 No 1 Juni 2019

Juditha, Christiany. (2015), Televisi Lokal dan Konten Kearifan Lokal (Studi Kasus di Sindo TV Kendari), Jurnal penelitian Komunikasi dan Pembangunan, Vol. 16 No. 1 Juni 2015 : $49-64$
Merkin, Rebecca S. (2009). Cross-cultural communication patterns - Korean and American Communication, Journal of Intercultural Communication, ISSN 1404-1634, issue 20, May 2009.

ZhongPeng,Ren dan PingWu,Wei .(2019). Measuring communication patterns and intercultural transformation of international students in crosscultural adaptation, 2019, International Journal of Intercultural Relations Volume 70, May 2019, Pages 78-88

Rotgers, Spencer Julie and McGovern, Timothy. (2002) Attitudes toward the culturally different: the role of intercultural communication barriers, affective responses, consensual stereotypes, and perceived threat, International Journal of Intercultural Relations, Volume 26, Issue 6, November 2002, Pages 609-631

Harahap, Suheri (2018). Konflik etnis dan agama di Indonesia, file:///C:/Users/Acer/Downloads/5096-102091-PB\%20.pdf, 21 October 2020

Saputro, Imam. (2018). Ini Dia Kunci Keharmonisan Warga Multikultur di Kota Tua Ampenen NTB. https://solo.tribunnews.com/2018/05/16/ini-kuncikeharmonisan- warga-multikultur-di-kota-tuaampenan-ntb. 23 October 2020

Antara news.com. (2019). Melestarikan Kearifan Lokal Gumi Sasak. https://mataram.antaranews.com/nasional /berita/797826/ melestarikankearifan- lokal-gumi- sasak? utm source $=$ antaranews \&utm_medium $=$ nas ional\&utm_ campaign=antaranews, 19 November 2020

Indrawan, Jeny. (2014). Kearifan Lokal Suku Sasak dan Suku Bali dalam Upaya Rekonsiliasi Konflik.ojs.uph.edu, 10 October 2020

CNN Indonesia. (2019). Perang Topat Perang Pemersatu Islam dan Hindu di Lombok. (https://www.cnnindonesia.com/gayahidup/20191213193601-269-456855/perangtopat-perang-pemersatu-islam-dan-hindu-dilombok. 12 September 2020

Zaremba, Yenni Vergatanti (2014) Nilai-Nilai Kearifan Lokal Sasak Berwawasan Multikultural Guna Membangun Integrasi Sosial Masyarakat di Lombok Barat diakses dari repository.upi.edu. 10 October 2020 